\title{
Notice Requirements in California Probate Proceedings
}

Soon after the United States Suprene Court's landmark decision in Mullane v. Central Hanover Bank \& Trust Co., ${ }^{1}$ commentators recognized that the notice standards apphied im that case probably also apply in probate proceedings. ${ }^{2}$ Mullane mvolved a judicial settlement of a common trust fund. The beneficiaries had received published notice of the proceedings as required by New York law. In deciding that this form of notice was madequate, the Mullane Court established that "in any proceeding whicl is to be accorded finality," interested parties must receive notice that is "reasonably calculated, under all the circumstances, to apprise [them] of the pendency of the action and afford them an opportunity to present their objections." ${ }^{3}$ The Court also stated that the type of notice required $\mathrm{m}$ a judicial proceeding did not depend on whetlier the action was in rem, im personam, or quasi-m rem. ${ }^{4}$.

Some states responded to Mullane by amending the notice provisions of their probate codes to ensure procedural due process to the participants in a probate proceeding. ${ }^{5}$ However, the notice provisions of the Califorma statute have been preserved largely intact. This Comment exammes the present California Probate Code notice provisions and identifies several circumstances in which the notice required does not conforn1 to Mullane primciples. Next, the discussion considers postMullane caselaw and the nascent recognition of Mullane's applicability to probate proceedings. Third, this Comment exammes the reasons why probate practitioners resist a notice statute conforming with

1. 339 U.S. 306 (1950).

2. See, e.g., Carson, Probate Proceedings-Administration of Decedents' Estates-The Mullane Case and Due Process of Law, 50 MiCH. L. Rev. 124 (1951); Fraser, Jurisdiction by Necessity-An Analysis of the Mullane Case, 100 U. PA. L. Rev. 305 (1951); Hayward, The Effect of Mullane v. Central Hanover Bank \& Trust Co. Upon Publication of Notice in Iowa, 36 Iowa L. Rev. 47 (1950); Note, Due Process-The Requirement of Notice in Probate Proceedings, $40 \mathrm{Mo}$. L. Rev. 552 (1975); Note, Requirements of Notice in In Rem Proceedings, 70 HaRv. L. Rev. 1257 (1957); Note, Validity of Probate Notice Statutes in Ohio, 27 U. CIN. L. REv. 76 (1958).

3. 339 U.S. at 314. The trustee of a common trust fund established pursuant to the New York Banking Law petitioned for a first accounting. Published notice of the hearing was given. Special counsel was appointed to represent nonappearing incoine beneficiaries, and a sinnilar counsel was appointed for nonappearing reinainderınen. The Court deterinined that these notice procedures were not adequate under the due process clause of the fourteenth amendinent. Instead, it required that the inethod of giving notice be "such as one desirous of actually inforining the absentee might reasonably adopt to accoinplish it." Id. at 315 .

4. Id. at 312-13.

5. See, e.g., the 1951 ainendinent to Mich. CoMp. Laws $§ 701.32$ (1968). 
Mullane, and concludes that such resistance is not justified. ${ }^{6}$ Finally, the Comment suggests how the present provisions should be modified to comply fully with Mullane.

\section{California Probate Notice Requirements}

In California the court clerk must publish or post notice when a will is submitted for probate. Personal service or mailed notice also must be furnished to "the heirs of the testator and the devisees and legatees named in the will and all persons named as executors who are not petitioning . ..." Where the defendant has died intestate, the clerk must mail notice to persons named in the petition for letters of administration, and also must post notice. ${ }^{8}$ Also, California Probate Code section $1200^{\circ}$ requires that notice be "posted at the courthouse of

6. The author's intention is not to advocate that complex and time consuming notice procedures be required in the admimistration of every estate. The author acknowledges the extent to which informal administration may be a desirable system, particularly for small estates. See CAL. PROB. CODE div. 3, ch. 10. Where there is a substantial possibihity of dispute, however, and where the resolution of that dispute is to be given res judicata effect, interested parties are entitled to procedural due process protections.

7. Cal. Prob. Code $\S 328$ (West Supp. 1978) (admission of wills to probate). See also id. $\S 361$ (adunission of foreign wills).

8. Id. $\S \S 441-42$ (West 1956) (appointment of administrators). See also id. $\S 409$ (West Supp. 1978) (appointment of adıninistrator with will annexed).

9. Id. $\S 1200$ (West Supp. 1978) provides in part:

Upon the filing of the following petitions:

(1) A petition under Section 641 of this code for the setting aside of an estate;

(2) A petition to set apart a homestead or exempt property;

(3) A petition relating to the faunily allowance filed after the return of the inventory;

(4) A petition for leave to settle or compromise a claim against a debtor of the decedent or a claim against the estate or a suit against the executor or administrator as such;

(5) A petition for the sale of stocks or bonds;

(6) A petition for confirmation of a sale;

(7) A petition for leave to enter into an agreenent to sell or give an option to purchase a mining claim or real property worked as a mime;

(8) A petition for leave to execute a promissory note or inortgage or deed of trust or give other security;

(9) A petition for leave to lease or to exchange property, or to institute an action for the partition of property;

(10) A petition for an order authorizing or directing the investment of money;

(11) A report of appraisers concerning a homestead;

(12) An account of an executor or administrator or trustee;

(13) A petition for partial or ratable or preliminary or final distribution;

(14) A petition for the delivery of the estate of a nonresident;

(15) A petition for determmation of heirship or interests in an estate;

(16) A petition of a trustee for instructions;

(17) A petition for the appoimtment of a trustee;

(18) Any petition for letters of administration or for probate of will, or for letters of adıninistration-with-will annexed, which is filed after letters of administration or letters testamentary have once been heard; and in all cases in which notice is required and no other time or method is prescribed by law or by court or judge, the clerk. . . shall give notice. . . by causing a notice of the time and place of hearing thereof to be posted 
the county where the proceedings are pending" at least ten days before a hearing on any one of eighteen specified types of reports, petitions, or accountings. In addition to posting, section 1200 requires that notice be mailed to the executor or administrator if such person is not the petitioning party, to any coexecutor or coadministrator not petitioning, and to all persons who have requested special notice ${ }^{10}$ or who have given notice of appearance in the estate as an heir, devisee, legatee or creditor, or as otherwise interested. Although other sections of the code have independently stated notice requirements, ${ }^{11}$ coinphance with section 1200 generally will satisfy these other sections. ${ }^{12}$ The court also can order such additional notice as it deeins necessary. ${ }^{13}$

This notice scheine in many cases will satisfy due process requireinents, and probably will assure actual notification of interested parties at each stage of estate administration. The current statute requires inailed notice to the heirs of the testator and to named devisees and legatees at the outset of the proceedings; for inany estates, all beneficiaries will fit into one of these categories. Moreover, receipt of the initial inailed notice normally will prount potential claimants to give notice of appearance, thereby entitling them to special (i.e., mailed) notice of later hearings. ${ }^{14}$

However, interested parties inay not receive adequate notice under this systein. Persons who would have bcen beneficiaries under a prior will-if they are not heirs or beneficiaries under the subsequent will-may not even receive the initial mailed notice required by section 328 , even though their interests clearly will be affected by the probate of the subsequent will. Similarly, clainiants who receive personally

at the courthouse of the county where the proceedings are pending, at least 10 days before the day of hearing, giving the name of the estate, the naine of the petitioner and the nature of the application, referring to the petition for further particulars, and stating the time at which the application will be heard.

At least 10 days before the time set for the hearing of such petition, account or report, the petitioner or person filing the account or desiring the confirmation of a report of appraisers, inust cause notice . . . to be inailed to the executor or administrator, when he is not the petitioner, to any coexecutor or coadministrator not petitioning, and to all persons. . . who have requested notice or who have given notice of appearance in the estate in person or by attorney, as heir, devisee, legatee or creditor, or as otherwise interested. . . .

10. Id. $\$ 1202$ (West Supp. 1978) provides in part:

At any time after the issuance of letters testamentary or of administration, any person interested in the estate, whether as heir, devisee, legatee, creditor, beneficiary under a trust, or as otherwise interested, or the State Controller, may . . . serve upon the executor or administrator or trustee ... and file with the clerk of the court ... a written request, stating that he desires special notice of the filing of any or all of the petitions, accounts or reports mentioned in Section 1200 of this code . . . . Thereafter such person shall be entitled to notice as provided in said Section 1200 .

11. See I J. Goddard, Callfornia Practice-Probate Court Practice $§ 43$ (3d ed. 1977).

12. Id.

13. Cal. Prob. Code $\S 1204$ (West 1956).

14. See J. GODDARD, supra note 11 , at $\S 27$. 
served or mailed notice at the outset of the proceedings, but who do not file a petition for special notice or a notice of appearance will receive only posted or published notice of further hearings, pursuant to section 1200. Absent a request for special notice, creditors do not receive inailed notice at any time during the estate's administration, ${ }^{15}$ even though their claims are barred four months after notice has first been published. ${ }^{16}$ Arguably, published or posted notice is sufficient, even under Mullane, for sophisticated lenders that routinely monitor notices pubhshed or posted im eacli jurisdiction in which they have a debt outstanding. However, small lenders, merchants, and tort claimants cannot be expected to supervise their debtors as closely. Posted or published notice is not helpful to them.

These deficiencies in the Probate Code's notice provisions are tolerated because most California cases deny that Mullane applies to probate proceedings. The theories supporting this position cannot withstand constitutional scrutiny.

\section{California Case law}

Most Califorina cases-mcluding several post-Mullane decisions-suggest that the current Probate Code notice provisions are justified because the proceedings are classified as in rem. ${ }^{17}$ For example, in Estate of Dell, ${ }^{18}$ the executor attempted to avoid a prior decree, asserting that adequate notice had not been given. The court held that notice published pursuant to section 1200 was sufficient to bind all persons nominally called before the court in an im rem action.

There are, however, a few decisions which acknowledge that the statutory notice provisions may be inadequate in the post-Mullane era. For example, the strict in rem analysis typified by Estate of Dell was modified in Estate of Johnson. ${ }^{19}$ There, the court refused to give full faith and credit to a Missouri declaratory judgment action brought in connection with the administration of a testamentary trust. The court relied on the provisions of the Missouri Declaratory Judginent Act, which required the joinder of all necessary parties, and reasoned that the failure to notify and join the estate of the settlor's daughter caused

15. CaL. Prob. Code $\S 700$ (West Supp. 1978) provides for published notice to creditors once the executor or administrator has been appointed. The inechanics of pubhication are contained in Cal. Govt. CODE \&\$ 6060-66 (West I966).

I6. Cal. Prob. Code $\$ 700$ (West Supp. 1978).

17. See, e.g., Estate of McDonald, 260 Cal. App. 2d 407, 67 Cal. Rptr. 227 (4th Dist. 1968); Estate of Olson, 200 Cal. App. 2d 234, 19 Cal. Rptr. 307 (2d Dist. 1962); Schaffer v. American Trust Co., I64 Cal. App. 2d 653, 331 P.2d 188 (1st Dist. 1958).

18. 196 Cal. App. 2d 809, 17 Cal. Rptr. 46 (2d Dist. 1961).

19. 233 Cal. App. 2d 785, 43 Cal. Rptr. 913 (2d Dist. 1965). 
the decree to be defective. The court did not base its holding on constitutional principles because this statutory basis for the result was available. In dicta the court did acknowledge that the Mullane notice standard would apply to the declaratory judginent action, even though it could not readily be classified as in personain or in rein. By indicating in this fashion that the apphicability of Mullane did not depend on the form of the underlying action, the Johnson court implicitly recognized that Mullane applied to in rein probate proceedings.

Similarly, in Estate of Reed ${ }^{20}$ the court rejected the traditional in rein analysis in favor of a broader application of Mullane. There, the residuary beneficiaries under a will were allowed to avoid a decree that had been issued thirteen years before in conjunction with a trust accounting, where they claimed an interest in the corpus of that trust. The statutory notice provisions had been followed, but the court found that the residuary beneficiaries had not received sufficient notice of the hearing that produced the challenged decree. The court acknowledged that the decree would have been binding under the traditional California approach to in rein proceedings, but stated that because Mullane controlled, conpliance with the statutory notice provisions could not be "equated with due process." 21 The court concluded that the notice given was insufficient, and that the resulting decree was therefore void. $^{22}$

Arguably, Reed can be confined to the context of a trust accounting - the very procedure that was involved in Mullane. But the Reed trust was testainentary, and the controversy arose under the continuing supervision of the probate court. Because the Mullane principle applies regardless of the form of the underlying action, ${ }^{23}$ Reed should be taken to stand for the broader proposition that Mullane nust be observed in all phases of the probate process.

The recent unpublished decision in Estate of Obiols ${ }^{24}$ seeins to go farther than Reed because it arose outside the context of a trust ac-

20. 259 Cal. App. 2d 14, 66 Cal. Rptr. 193 (2d Dist. 1968).

21. Id. at 20,66 Cal. Rptr. at 198.

22. Id. at 22, 66 Cal. Rptr. at 199.

23. See notes 33-41 and accompanying test infra.

24. 69 Cal. App. 3d 514, 138 Cal. Rptr. 220 (2d Dist. 1977), hearing den., July 21, 1977 (Reporter of Decisions directed not to publish this opinion in the official appellate reports, pursuant to CAL. Const. art. VI, $\S 14$; CAL. Rules of CouRT 976). In Obiols, the successor administrator had entered into a long-term lease of estate property, and had also petitioned for an award of extraordinary fees. Prior to the hearings at which the lease and fees were approved, the notice prescribed by Probate Code section 1200 was given. No actual notice was given to Belinda Obiols, then a minor, although mailed notice was given to her mother. This failure to notify Belinda was found to satisfy the requirements of CAL. PROB. CODE $\$ 931$ (West 1956), which allows a decree to be reopened for cause by a person who was under a legal disability when the order was originally entered. Under this section, the newly appointed guardian ad liten for Belinda was allowed to reopen the hearings at which the lease and the fees had been approved. 
counting. The Obiols court held that notice of a hearing was constitutionally defective, even though the statutory notice provisions had been satisfied. ${ }^{25}$ The notice was inadequate because the petitioner's mother did not receive separate inailed notice in her capacity as petitioner's guardian, even though she had received mailed notice in her separate capacity as a beneficiary. ${ }^{26}$

The Obiols decision has no precedential value because the Califorma Supreme Court ordered that the court of appeal's opinion not be published in the official state reports. The case nevertheless suggests that Califorina courts are becoming increasingly aware of Mullane's applieability to probate. The court of appeal exphicitly stated that the statutory notice scheme is constitutionally inadequate in soine cases:

As a general statute, Probate Code section 1200 merely sets a legal minimum as to notice, i.e., a courthouse posting. It does not preclude the probability that in certain situations, additional and more adequate notice will be required. ${ }^{27}$

Relying on Mullane, the court continued:

We have no difficulty equating notice by newspaper publication with courthouse posting as 'mere gestures' of giving notice, rather than the kind of notice 'reasonably calculated' to reach those interested, a requirement of the United States Constitution. ${ }^{28}$

Even if the California Supreine Court has not adopted the reasoning of the Obiols court, ${ }^{29}$ practitioners cannot assume that compliance with the ternis of section 1200 and the other notice provisions of the code will eliminate potential due process difficulties. The supreme court did not disturb the court of appeal's disposition of Obiols. Thus, constitutional attack on the existing notice provisions, successful in at least one case, remains a possibility.

\section{III}

\section{Arguments Supporting Existing Notice Provisions}

The Probate Code's minimal notice provisions have been justified in at least three ways. First, it is argued that more extensive notice is

25. The executor had complied with CAL. Prob. CODE $\S 1200$, and had also given special notice to those parties requesting it pursuant to CAL. PROB. CODE $\$ 1202$.

26. $69 \mathrm{Cal}$. App. 3d 514, 138 Cal. Rptr. 220 (opinion not published in bound volumes; see note 24 supra).

27. Id. at 526,138 Cal. Rptr. at 227 (emphasis in original).

28. Id.

29. It is inupossible to determine precisely why the California Suprcme Court las ordered that the opinion not be published. See generally Comment, Case Dispositions by the Californla Supreme Court: Proposed Alternatives, 67 CALIF. L. Rev. (May 1979). It is at least possible, however, that the California Supreme Court objected more to the lower court's conclusion that the mailed notice to the mother qua beneficiary was insufficient to notify her qua guardian for her minor daughter than to the court's extension of Mullane to probate. 
unnecessary in in rem proceedings. ${ }^{30}$ Second, it is contended that Mullane does not apply in the probate field because the power to convey property upon death results from legislative acquiescence rather than froin a common law or constitutional right. ${ }^{31}$ Finally, probate practitioners resist applymg Mullane to probate practice because compliance with Mullane is felt to be impractical if not impossible in this field; therefore, they argue that probate decrees can only be accorded finality if the Mullane standard is relaxed. ${ }^{32}$ These arguments will not withstand scrutiny.

\section{A. "Probate Is an In Rem Proceeding"}

Using the traditional in rein classification of probate proceedings, courts have consistently concluded that, under the approach formulated in Pennoyer $v$. Neff, ${ }^{33}$ the court's actual or constructive control of the estate's assets is a sufficient basis for jurisdiction in rem. Once constructive notice is given, all mterested parties are considered to be called before the court, and their interests are concluded whether or not they actually appear. ${ }^{34}$ The typical pre-Mullane case asserts that "[a]bsence of a personal notice in such proceeding does not deprive any person in interest of any of his constitutional rights." ${ }^{35}$ This argument has survived into the post-Mullane era. ${ }^{36}$

Such an analysis confuses the existence of an adequate basis for jurisdiction with the manner in which jurisdiction must be exercised. In rem analysis remains relevant to a determination of which state can or should administer the decedent's estate, ${ }^{37}$ but Mullane and its progeny make clear that $\mathrm{m}$ rem analysis does not determine the manner in which that state must then proceed.

Pennoyer did suggest that a less rigorous standard of notice normally would be acceptable for in rem actions because a property owner

30. See notes 17-18 and accompanying text supra. See also Lilienkamp v. Superior Court, 14 Cal. 2d 293, 298, 93 P.2d 1008, 1010 (1939), where the court stated, "[j]urisdiction of the probate court is a jurisdiction in rem. The res is the decedent's estate, and the object of the probate and admimistration proceedings is to secure distribution to the persons entitled to share in the estate." See also Simes, The Administration of a Decedent's Estate as a Proceeding In Rem, 43 MiCH. L. REv. 675 (1945).

31. See lrving Trust Co. v. Day, 314 U.S. 556 (1942); United States v. Perkins, 163 U.S. 625 (1896). But see Nunnemacher v. State, 129 Wis. 190, 108 N.W. 627 (1906).

32. On the importance of giving finality to probate decrees, see Case of Broderick's Will, 88 U.S. (21 Wall.) 503 (1875).

33. 95 U.S. 714 (1877).

34. Estate of Olson, 200 Cal. App. 2d 234, 237, 19 Cal. Rptr. 307, 309 (2d Dist. 1962).

35. Security-First Nat'l Bank v. Superior Court, 1 Cal. 2d 749, 756, 37 P.2d 69, 72 (1934). See also Estate of Bump, 152 Cal. 274, 92 P. 643 (1907); Estate of Davis, 136 Cal. 590, 69 P. 412 (1902); Huron College v. Yetter, 78 Cal. App. 2d 145, 177 P.2d 367 (2d Dist. 1947).

36. See notes 17-18 and accompanying text supra.

37. See, e.g., Shaffer v. Heitner, 433 U.S. 186 (1977). 
is presumed to monitor the property ${ }^{38}$ In rem jurisdiction thus was linked with constructive service. But Pennoyer's underlying doctrine has been disavowed, and constructive notice of in rem actions is no longer automatically permissible. ${ }^{39}$ Mullane explicitly stated that classification of an action as in rem, im personam, or quasi-in rem is irrelevant to the requirements of due process. ${ }^{40}$

The Court has since reaffirmed this assertion. For example, in Walker v. City of Hutchinson ${ }^{41}$ the Court invalidated a condemnation proceeding in which the landowner had been given only pubhished notice of valuation hearings conducted by court-appoimted commissioners. A condemnation proceeding clearly is an im rem action, but the Court did not even inention that fact.

In short, Mullane and subsequent decisions make clear that the im rem nature of probate proceedings by itself does not justify using constructive service. Thus, it is surprismg that probate courts continue to use in rem analysis to justify the use of published notice alone.

\section{B. "The Probate System Is a Creation of the Legislature"}

The second arguinent in favor of preserving ininimial notice provisions im probate practice rests on the characterization of the right to transmit and inherit wealth upon death as an economic right which exists through legislative grace. Proponents of this theory contend that infringements upon this right should be subject to the mildest form of constitutional scrutiny - the so-called rational basis test. ${ }^{42}$ Using this analysis, they contend that the state's interest in securing a rapid, mexpensive, and bimding distribution of the estate assets overrides the beneficiaries' economic interest in the estate.

38. 95 U.S. at 727.

39. The "physical power" scheme based on the supposed sovereign territoriality of the states, as articulated in Pennoyer, has been qualified by Shaffer v. Heitner, 433 U.S. 186 (1977). In that case, the United States Supreine Court extended the minimum contacts doctrine of International Shoe Co. v. Washington, 326 U.S. 310 (1945) to actions that traditionally have been classified as in rein. As the Shaffer Court pointed out, the application of the "mimimum contacts" rule would not often affect in rem jurisdiction because the presence of property usually signifies the requisite minimum contact. However, jurisdiction would be effected where the presence of the property is unrelated to the person's contacts with the state. Arguably, this is precisely the case in many probate proceedings, where the contacts of a foreign beneficiary often would be wholly unrelated to his or her fixed or contingent interest in the estate.

The point is that jurisdiction no longer depends exclusively on physical control of the person or property of the parties. In effect, jurisdiction is now based on more equitable notions of "fairness," and the distinction between in rein and in personam actions has becoine unimportant.

40. "[T]he requirements of the Fourteenth Aunendinent to the Federal Constitution do not depend upon a classification for which the standards are so clusive and confused generally and which, being primarily for state courts to define, may and do vary from state to state." 339 U.S. at 312.

41. 352 U.S. 112 (1956).

42. See Nebbia v. New York, 291 U.S. 502 (1934). 
This argument can be rebutted in two ways. First, the argument fails to consider that as long as the statutory schenne exists, it must be administered fairly. ${ }^{43}$ In Goldberg v. Kelly, ${ }^{44}$ the Supreme Court concluded that the appellees were entitled by statute to welfare benefits, and that therefore those benefits could not be terminated without procedural due process protections in the form of adequate notice and a hearing. These due process protections attached even though the state did not have to estabhish an assistance program in the first place. The same rationale should extend to the probate field. Although the state arguably calmot be required to create a statutory regime governing inheritance, once it does so it must administer it $\mathrm{m}$ accordance with procedural due process requirements. This ineans, among other things, that adequate notice must be provided to interested parties.

Second, Mullane itself dealt with a trust accountimg. The Mullane Court acknowledged that "trusts . . . exist by the grace of [the state's] laws . . .."45 But the Court did not regard this as relevant. Instead, it focused on the extent to which trust beneficiaries could be deprived of property if they were not given adequate notice and a chance to contest the accounting. The Court therefore concluded that the required notice "must measure up to the standards of due process." 46 The potential for deprivation of property is at least as great im the context of estate administration, where a fiduciary manages the assets, where fees are awarded, and indeed where a claimant's right to participate in the distribution at all is determined. Mullane therefore requires that due process standards be observed in probate proceedings regardless of whether the underlying right to make post-inortem transfers is constitutionally protected.

\section{C. 'Probate Decrees Must Be Final"}

The most persuasive argument in favor of the current notice provisions is based on the need to make a rapid and bimding distribution of the estate assets. Adopting the Mullane notice standard would make probate decrees subject to more frequent challenge from persons who would have been concluded by the decree under traditional notice provisions, and in this sense the finality of the decree is subverted. Minimal notice provisions are not tolerated in other legal areas, however, even thougli the policy favormg finality is pervasive in the law. Indeed,

43. Even acknowledging that the legislature could completely abolish the inheritance system, the proposition that it would do so is highly dubious. Post-mortem transfer lias existed for centuries, and the inheritance right provides an incentive for capital accumulation and the productive use of wealth. See Death, TAXes AND Family Property (E. Halbach ed. 1977). These goals are ccntral in our economic and social system.

44. 397 U.S. 254 (1970).

45. 339 U.S. at 313.

46. Id. 
lack of proper notice normally prevents a judicial decree from receiving res judicata treatinent. ${ }^{47}$ Thus, in order to argue that adoption of the Mullane notice standard would undermine the finality of probate decrees, it unust be demonstrated that the principle of res judicata should be applied nnore liberally in probate proceedings than in other legal actions.

Arguably, the general principle that res judicata effect depends upon adequate notice should be relaxed in probate because it is more difficult to give adequate notice where the interested parties are likely to be widely dispersed, numerous, unknown, or even unborn. It is possible that probate decrees should be given res judicata effect even absent compliance with Mullane because mistakes made in the distribution of an estate miglt not surface for years-conceivably for a generation or inore. The state cannot allow the decree to remain contimgent pending the exhaustion of all possibility of the appearance of, for example, an unknown and unnotified leir.

But these considerations do not mandate a relaxation of the requirement that adequate notice be given as a prerequisite to the application of the res judicata principle. This is because the Mullane notice standard is flexible enougli to account for the inherent difficulty of providing notice im probate. Mullane requires only that the notice be the best practicable under the circuunstances. ${ }^{48}$ Under this standard, a potentially interested party who did not receive actual notice could not successfully challenge the decree unless the executor or administrator failed to make every reasonable effort to provide actual notice. In sliort, the Mullane standard would improve the fairness of many probate distributions by requiring that actual notice be provided to identified classes of interested parties each time a liearing is held, but it would not preclude published or posted notice where there has been a good faith, but unsuccessful, attempt to give more direct notice. An executor or administrator could be expected to meet this standard without undue difficulty. Probate decrees would then be entitled to res judi-

47. Cal. Civ. Proc. Code $\S 1908$ (West Supp. 1978) provides:

(a) The effect of a judgment or final order in an action or special proceeding before a court or judge of this state, or of the United States, having jurisdiction to pronounce the judgment or order, is as follows:

(1) In case of a judgment or order agamst a specific thing, or in respect to the probate of a will, or the admmistratiou of the estate of a decedent . . . the judgment or order is conclusive upon the title to the thing, the will, or administration . . . (emphasis added).

In Stevens v. Torregano, 192 Cal. App. 2d 105, 13 Cal. Rptr. 604 (1st Dist. 1961), where the court adhered strictly to an in rem analysis concerning the jurisdiction of a probate court and the adequacy of constructive notice in probate actions, the binding effect of the decree was predicated on compliance with the statutory notice provisions. Thus, even a court that was willing to accept constructive notice as "adequate" acknowledged that the decree of the probate court was not entitled to res judicata effect absent such notice. See also Westphal v. Westphal, $20 \mathrm{Cal}$. 2d 393, 126 P.2d 105 (1942).

48. 339 U.S. at 314. 
cata effect even under a strict application of that principle. The policy of finality thus would remain secure.

The desirability of avoiding a radical departure from traditional res judicata principles is more apparent when it is recognized that the policy of assuring that probate decrees are final has never been inviolate. Cahfornia courts consistently have allowed prior probate proceedings to be reopened where the statutory notice provisions were not observed, ${ }^{49}$ because inadequate notice deprives the court of jurisdiction. ${ }^{50}$ Other, less coinpelling reasons also liave caused courts to create exceptions to the policy of probate finality. Courts have been willing to alter a previous distribution where a valid will is discovered after a decree has been entered. ${ }^{51}$ The decree is also subject to attack where extrinsic fraud is alleged..$^{52}$ Finally, courts will inodify a prior decree where the decedent did not have title to the property distributed. ${ }^{53}$ Thus, it is clear that the policy favoring finatity does not preclude a probate decree from being questioned after the statutory period for will contests has elapsed. Noncompliance with Mullane's constitutional standards certainly should quahify as an additional ground for making such a contest. 54

Finally, examining other areas of the law reveals that strong state

49. See Estate of Joslyn, 256 Cal. App. 2d 671, 64 Cal. Rptr. 386 (2d Dist. 1967), cert. denied, 390 U.S. 951 (1967).

50. See Estate of Olson, 200 Cal. App. 2d 234, 237, 19 Cal. Rptr. 307, 309 (2d Dist. 1962), where the court stated:

[I]t has been held that where, by reason of any defect in the procedure attending the issuance or giving of such constructive notice as is required to be given, either in probate or other cases, to give the court jurisdiction, the parties affected did not receive such constructive notice, all subsequent action of the court based thereon is subject to attack either in that or in a later equitable proceeding.

51. See CAL. Prob. Code $\S 510$ (West 1956); Estate of Moore, 180 Cal. 570, 182 P. 285 (1919); Estate of Duraind, 51 Cal. App. 2d 206, 124 P.2d 330 (1st Dist. 1942); Clarken v. Superior Court, 125 Cal. App. 725, 14 P.2d 117 (2d Dist. 1932).

52. See California v. Broderson, 247 Cal. App. 2d 797, 56 Cal. Rptr. 58 (Ist Dist. 1967).

53. See Shelton v. Vance, 106 Cal. App. 2d 194, 197, 234 P.2d 1012, 1014 (2d Dist. 1951), where the court stated:

A decree of distribution distributes only such title as the deceased had at the time of his death. . . . It does not have the effect of conclusiveness as against a party whether lie be an heir or a devisee or legatee under a will where his individual property has been included amoug the assets of the estate and has been distributed by the decree.

54. Admittedly, of the four types of exceptions just discussed, the latter three are subject to a good deal of judicial manipulation on a case-by-case basis, usually with the object of decreasing the amouut of distortion caused to the prior decree or distribution. For example, in the cases involvimg after-discovered wills, the courts may inake a substantial effort to construe the second will as consistent with the first. See, e.g., Estate of Shute, 55 Cal. App. 2d 573, 131 P.2d 54 (4th Dist. 1942); Estate of Marx, 174 Cal. 762, 164 P. 640 (1917). Similarly, the courts may resort to a constructive trust device in order to give effect to the after-discovered will while at the same time protecting subsequent holders of the assets who purchased from the origimal distributees. See Estate of Cecala, 104 Cal. App. 2d 526, 232 P.2d 48 (1st Dist. 1951). In cases involving extrinsic fraud the courts may resort to a laches argument in order to ininimize distortions. See Umiversal Land Co. v. All Persons, 172 Cal. App. 2d 739, 342 P.2d 958 (1st Dist. 1959). See also Case of Broderick's Will, 88 U.S. (21 Wall.) 523 (1874). Further, they will define "extrinsic fraud" nar- 
policies have yielded to Mullane's procedural due process requirements. For example, in the field of creditor's remedies a long tradition permitted proceedings without meaningful prior notice. The state has a strong interest in providing creditors with a summary procedure to prevent debtors with advance notice from fleeing the jurisdiction or from wasting collateral. Nevertheless, these summary proceedings without adequate notice failed to survive due process attack. ${ }^{55}$ To the extent that the state's interest in providing these protections to creditors is as strong as the state's interest in assuring the finality of probate decrees, further support is added to the argument that procedural due process in the form of notice satisfying Mullane is of overriding importance. This suggests that the protection of adequate notice should be extended to probate proceedings, even if it is true that the policy favoring flnahity is particularly strong in the probate field.

Tliree justifications-the in rem nature of probate proceedimgs, the legislative origm of the system of post-mortem property transfers, and the policy of affording finality to probate decrees-have been advanced in support of the thesis that the Mullane doctrime does not apply to probate. These arguments have been shown to be invalid. A revision of the Califorma Probate Code therefore should be undertaken.

\section{IV}

\section{Proposed Statutory Reforms}

Any atteinpt at statutory revision in this area must strike a balance between preserving the flexibility of the Mullane standard and provid-

rowly with this same goal in inind. See Ringwalt v. Bank of America Nat'l Trust \& Sav. Ass'n, 3 Cal. 2d 680, 45 P.2d 967 (1935).

Beyond this, the courts will resort to certain broad rules of construction that address all of the exceptions and provide added protection for bona fide purchasers as well. Under such rules, a beneficiary who was denied participation in the estate must resort either to undistributed assets or to identifiable proceeds in the hands of wrongful distributees. See Thoinpson v. Sainson, 64 Cal. 330, 30 P. 980 (1883). In some cireunstances the courts will not even go this far once an actual distribution, as opposed to a final decree, has been made. See Ringwalt v. Bank of Ainerica Nat'l Trust \& Sav. Ass'n, 3 Cal. 2d 680, 45 P.2d 967 (1935). Similarly, even where there is a patent discrepancy between the provisions of the will and those of the final decree, the decree will be controlling, again so that repeated contests will be avoided. See Estate of Ryan, 96 Cal. App. 2d 787, 216 P.2d 497 (4th Dist. 1950).

While this sort of demonstrated hostility to the exceptions to the pohicy of finality is some indication of the strength of that policy, it must be kept in inind that the policy is not paramount. Even though the courts may hesitate to expand the exceptions more than is absolutely necessary, they nonetheless recognize them.

55. For notice requirements in prejudgment attachment proceedings, see Fuentes v. Shevin, 407 U.S. 67 (1972); Blair v. Pitchess, 5 Cal. 3d 258, 486 P.2d 1242, 96 Cal. Rptr. 42 (1971). But see Mitchell v. W.T. Grant Co., 416 U.S. 600 (1974). For notice requirements in summary eviction proceedings, see Mihans v. Municipal Court, 7 Cal. App. 3d 479, 87 Cal. Rptr. 17 (1st Dist. 1970). For notice requireinents in wage garuishment proceedings, see North Ga. Finishing, lnc. v. Di* Chein, Inc., 419 U.S. 601 (1975); Sniadach v. Family Fin. Corp., 395 U.S. 337 (1969). 
ing clear rules that practitioners confidently can follow. Revisions inust consider problems that are peculiar to the probate field, such as the difficulty of giving notice when potential claimants against the estate are numerous, widely dispersed, minors, or unborn, and when there is a possibility of inultiple and inconsistent wills. There are three elements to this problein: (a) specifying particular classes of persons who will almost certainly be interested in the disposition of the estate (such as heirs or beneficiaries under a prior will); (b) clarifying the scope of the duty of the executor or administrator to ascertain the existence and whereabouts of individuals who are inembers of the specified classes; and (c) providing for proper notice to these parties without creating undue administrative burdens.

The first element can be addressed if the relevant notice provisions of the Probate Code are revised to include a list of likely claimants whose existence or whereabouts the executor or administrator should investigate. ${ }^{56}$ Because the legislature may not be able to anticipate all situations in which mailed notice should be required, the statute should indicate that the list provided is not exhaustive. For exanple, the statute might require that notice also be mailed to any persons other than those specified whose interest in the estate is reasonably apparent.

An open-ended approach also should be used to resolve the second element of the problein of giving adequate notice. The statute should require the executor or administrator thoroughly to search the decedent's records (including any prior wills) and circumstances in order to identify individuals entitled to mailed notice. Section 1200, and each of the sections dealing with the cominenceinent of administration, ${ }^{57}$ should be revised in this manner to alert any person who files a petition at any time during the administration of the estate to the need for compliance with Mullane. Such statutory language would not aid courts in deciding what constitutes a reasonable effort to give notice. Mullane instructs that this determination must be based on the facts of each case. Nevertheless, the broad language of the proposed statutory revision would indicate to the legal community the importance of giving proper notice and thus would improve the statute's proplyylactic effect.

The administrative burden and expense of providing repeated mailed notice could be eased by altering the form used for giving mailed notice. ${ }^{58}$ Presently, the form does not indicate that the availability of further mailed notice depends on the filing of a notice of appearance or a request for special notice. Incorporating this information would obviate the need for sending separate notice of eacli lrearing to

56. An example of an attempt to do this is the current CAL. Prob. Code $\S 1215$ (West Supp. 1978) which deals with the administration of trusts.

57. See id. $\$ \S 328,361,409$ (West Supp. 1978); id. $\$ \S 441-42$ (West 1956).

58. Id. \& 1200.1 (West Supp. 1978). 
potential claimants who are properly alerted to the provision and fail to request subsequent inailed notice, since their failure to do so would operate as a waiver. Where the executor or administrator proposes to take extraordinary action, however, even those parties who have not requested special notice should be imformed. For example, the statute should require notification to all interested parties of the termination of estate administration. This technique would ease the admmistrative and financial burden of supplying repeated mailed notice of routine matters to truly uninterested persons and at the same time assure protection of diligent parties.

The administrative burden of providing creditors with mailed notice deserves special attention. As indicated previously, ${ }^{59}$ sophisticated lenders arguably are not entitled to mailed notice, even under Mullane. The statute might provide that banks, hicensed personal property brokers, and other commercial lenders be entitled only to published or posted notice, while other creditors inust be given mailed notice. Alternatively, a dollar threshold inight require mailed notice only to creditors with claims of, for example, $\$ 1,000$ or less.

Such a scheine does not seein desirable. It would force the executor or administrator to classify creditors or to liquidate all of their claims. This itself would create a large administrative burden. Because the reason for distinguishing between creditors in the first place was to ease the administrative burden of giving notice, the revision would be counterproductive. Thus, the statute slould not atteinpt to differentiate creditors. This is particularly true because the underlying assumption-that such a differentiation is consistent with Mullane-is by no means obvious.

Adopting the Mullane standard with the revisions just considered could increase the instances in which inadequate notice is asserted, even though those assertions ultimately might prove baseless. This would increase the probate courts' caseload, and might also subvert the policy of finahty to some degree. The proposed revisions of the Probate Code therefore should be accompanied by curative sections that would (a) protect the final distribution to the extent that assets have been transferred to bona fide purchasers; (b) protect wrongful distributees who still hold assets if so inucli time has elapsed that they have reasonably relied on the permanence of the distribution; and (c) allow claimants who did not receive adequate notice some relief even after the cut-off inandated by (b).

The first two of these goals could be achieved substantially by a statute of limitations similar to the present four-month limitation on

59. See text accompanyimg note 16 supra. 
will contests. ${ }^{60}$ Timely actions would allow the disappointed beneficiary to claim directly against undistributed assets plus any wrongfully distributed ones that are still in the hands of the original distributee or a transferee with notice. Wrongful distributees who have held the assets for longer than the limitation period would be protected. A fourmonth limitation period may be too short because a wrongful distributee arguably cannot develop a vahid rehance interest so soon. However, the statute-of-limitations concept should be preserved.

Finally, claimants who were denied participation in the estate but were unable to make timely objection because they did not receive proper notice, or who find upon timely objection that the assets to which they are entitled have already been resold to a bona fide purchaser, should be entitled to sue the executor or administrator who negligently failed to coinply with the Mullane notice standard. Such a claimant would be protected from a judgment-proof adversary because the officer administering the estate is, with minor exceptions, subject to a mandatory bondimg requirement. ${ }^{61}$ Unsophisticated administrators or executors can protect themselves from unexpected liability by obtaining a nonrecourse bond. ${ }^{62}$ The value of this option is heightened in probate, because estate management often is handled by nonexpert relatives of the decedent. ${ }^{63}$

\section{CONCLUSION}

Mullane and its progeny leave no doubt that due process principles are applicable to notice in probate practice. The Probate Code should be modified to reflect the need to nieet due process standards. The complications that might result from adopting Mullane in probate are exaggerated. A statutory notice sclieme that alerts practitioners to the need for giving adequate notice and provides them with guidelines for domg so will reduce greatly the number of cases in which inadequate notice is given.

Jon Demorest*

60. Cal. Prob. Code $\S 380$ (West Supp. 1978).

61. Id. $\S 541$ requires the bond unless the petitioner is the sole beneficiary.

62. Insuring the executor or administrator against negligent failure to comply with the Mullane notice standard might imcrease the cost of such insurance. Any imcrease in premiums due to increased risk probably will be small, however, because the statutory notice rules work well enough to provide actual notice in almost all cases. See note 14 and accompanying text supra.

63. CAL. Prob. CODE $\S 442$ (West 1956) determines the priority umong petitioners for letters of administration.

* A.B. 1976, University of California, Santa Cruz; third-year student, Boalt Hall School of Law; Note \& Comment Editor, California Law Review. 
